1016

\title{
高・深屈曲対応型人工膝関節インサートの光弾性応力解析*
}

\author{
廣 川 俊 二*1, Ansarullah LAWI*2 \\ 関 屋 圭 輔*3, 澈 口 純一 郎*4
}

\section{Photoelastic Study of Contact Stress on the Tibial Insert of Knee Prosthesis for High/Deep Flexion}

\author{
Shunji HIROKAWA*5, Ansarullah LAWI, \\ Keisuke SEKIYA and Junichiro TAKIGUCHI \\ *5 Department of Mechanical Engineering, Graduate School of Engineering, Kyushu University, \\ 744 Motooka, Nishi-ku, Fukuoka-shi, Fukuoka, 819-0395 Japan
}

\begin{abstract}
This paper presents the experimental results of photoelasticity for determining the magnitude and distributions of stresses on the polyetheren insert of typical three types of posterior stabilized knee prostheses designed to attain high/deep knee flexion. Three prostheses used in the experiment were a conventional posterior stabilizer knee, Scorpio NRG (Stryker Co., USA), Bi-surface knee (Kyocera Inc., Japan) with a unique design with a ball-and-socket joint and CFK (Complete Flexion Knee, Japan Medical Material Co., Japan) which we have developed by further improving the Bisurface so as to make a complete knee flexion. Epoxy resins were selected to fabricate the tibial insert models. Special equipment was used to apply $2 \mathrm{~kg}$ force on the model by setting knee flexion angle at $0^{\circ}, 30^{\circ}, 60^{\circ}, 90^{\circ}$ and $120^{\circ}$ respectively. After that the stressed model was sliced in parallel with the saggital plane and photoelastic fringes in each slice were observed. The results demonstrated that while knee angle was smaller than $90^{\circ}$, shear stress on the lateral slice became highest for $\mathrm{Bi}^{-}$ surface, followed CFK and NRG was lowest, indicating NRG has high conformity as to the condylarinsert articulation. After knee angle bacame larger than $90^{\circ}$, shear stress on the mid-posterior slice became highest for NRG, followed Bi-surface and CFK was lowest. We may conclude that CFK has the optimal configuration especially at deep knee flexion from a load bearing viewpoint.
\end{abstract}

Key Words: Medical Engineering, Biomechanics, Experimental Stress Analysis, Knee Prosthesis, Photoelasticity, Complete Flexion, Post-Cam, Ball-Socket, Contact Stress, FEM

\section{1. 序}

本論文は光弾性法を用いた高・深屈曲対応型人工膝 関節の関節面接触部の応力測定に関するものである. 正常滕が自身の筋収縮力により達成できる最大屈曲角 度は約 $130^{\circ}$ であり，それ以上の屈曲は体重などの外 力が加わることで初めて達成されることから，2003 年 の第 33 回日本人工関節学会では, 外力による屈曲角 $130^{\circ}$ 以上の強制肢位を㯟の「深屈曲位」，単に膝を 深く屈曲させた状態を「高屈曲位」と定義することが 合意されている(1).

2005 年の統計によると，世界人口の約 1 / 3 はアジ ア・イスラム圏の人々であり(2), これらの人々は生活 習慣もしくは宗教上の理由で床面上での正座を必要と

* 原稿受付 2008 年 8 月 28 日.

*1 正員, フエロー, 九州大学大学院工学研究院 (汬 819-0395 福 岡市西区元岡 744)

*2 九州大学大学院工学府.

*3 学生員, 九州大学大学院工学㾈.

*4 准員, 九州大学大学院工学府.

E-mail : hirokawa@mech.kyushu-u.ac.jp
している. しかも最近では，アジア・イスラム圏で膝 関節置換術 (TKA: Total Knee Arthroplasty) を受ける 人々が増大している(3).人工膝関節は，元々，西欧で 開発されたため，洋式生活であまり必要とされない 高・深屈曲動作を適用対象に含めなかったが，近年に なって，欧米の人々の間にも TKA 後の可動域減少に 対する不満から, 高・深屈曲対応型人工膝関節に対す る関心が高まりつつある.

以上の経緯に基き, 現用人工膝関節の高屈曲対応型 への改良や，深屈曲動作実現を目指して，新たなデザ インの人工膝関節が提案されてきている(4)-(7),(10).

現用人工膝関節の改良に関しては，大腿骨後顆部を さらに丸めた形状にする方式が主流である ${ }^{(6)}$.

一方, 新たなデザインの人工関節の代表例としては, Bi-surface 型人工膝関節(京セラ(株) $)^{(7)}$ があり, すでに厚 生労衝省の認可を得て, 実用化されている. この人工 膝関節では，ユニークな形状のボールーソケットが高・ 深屈曲位での荷重支持機能を有する。ただし， 
Bi-surface 型の最大膝屈曲角度は約 $150^{\circ}$ に止まってお り正座位の実現には不十分である. 中にはBi-surface で正座が可能な患者もいるが，この時の膝姿位をX線 で撮影・観察した結果によれば，大腿骨顆之脛骨イン サートが離れており，正座位から立ち上がる際に脱臼 する恐れがある.

そこで, 筆者らの研究グループでは上記 Bi-surface 型をさらに改良することにより, 膝屈曲角度 $180^{\circ}$ の完 全深屈曲を目指した人工膝関節を開発した。この人工 膝関節はBi-surface 同様, ボールソケットを有してい るが, ボール位置が後方にオフセットしていおり、ソ ケットが前方上方部に突き出している. 筆者らはこの 人工膝関節を $C F K($ Complete Flexion Knee, 日本メデカ ルマテリアル(株) と名付 $\mathfrak{F}^{(8)}$, 厚生労衝省への認可申請 を準備中である。

人工膝関節では可動性, 安定性, 耐久性の3 者のバ ランスが重要とされている(3).この中, 可動性や安定 性に関しては設計段階でも評価が可能であるが，耐久 性に関しては，患者への適用を経ずにこれを評価する ことは極めて困難である.このため, 患者への適用が 未だ認可されていないCFKでは，いかにして耐久性評 価を行うかが大きな課題となっている.

一般に，人工関節の耐久性は主にポリエチレンイン サートの摩耗に支配されるため, インサートに作用す る応力值と応力分布状態を知ることが重要になる. 応 力解析に広く用いられている手法は FEM 解析と光弾 性法である.この中, FEM 解析が人工関節の応力解析 の主流になっていることは周知の通りであるが(9),(10),

FEM 解析の結果の妥当性を検証するには, 何らかの実 験を並行して実施することが重要である.

現用の FEM 解析の結果はメッシュの作り方いかん で大きく異なることが知られている. Ramesh らは, FEM のメッシュ問題を効果的に解決するためには光 弾性法の援用が不可欠であると述べている(11). FEM 解 析の基本は節点の変位（応力ではない）を求めること であるが，光弾性法の基本は（ひずみではなく）応力 分布を求めることである. 摩耗はせん断応力に起因し ており, 光弾性法はせん断応力測定を第一義とした実 験手段である.

以上のような理由により，筆者らは光弾性法を用い て, とくに高・深屈曲位における人工関節のせん断応 力值とその分布を求めることにした. 対象とした人工 膝関節は前述した Bi-surface と CFK, および現用人工 膝関節の代表である後方安定型(Posterior Stabilizer: PS type)人工膝関節の 3 種である.

\section{2. 対象人工滕筷節}

図 1 に本研究で対象とした 3 種の人工膝関節の外観 を示す. 図で, (a)は現用の後方安定型人工膝関節 Scorpio NRG(Non Restricted Geometry) (Stryker Co., USA), (b)が Bi-surface, (c)が CFK を示す.これら 3 者 はいずれも, 高・深屈曲の実現を目指して改良あるい は新規開発されたものである.

まず, 後方安定型(PS type)とは, 後十字勒帯切除後 の膝に対し, 脛骨ポストと大腿骨力ムの間の干渉によ り, 膝屈曲に伴って大腿骨コンポーネントが脛骨面上 を後方移動（ロールバック）するように設計された人 工膝関節のことである. このタイプの代表的な人工関 節である NRG(図 1,(a))は, 膝の高屈曲位においても十 分な回旋自由度を持たせるため脛骨インサートの関節 面が球面アークを描くように設計されている.さらに, ポストーカム形状も回旋運動しやすい形状になってい る(10), (12)

次に，Bi-surface 型(図 1, (b))は，既に述べたように， 脛骨の中央側後方にユニークなボールーソケット部を 有しており，これが前述した NRG のポスト-カムと同 様の機能を果たすとともに, 高屈曲位では本来の大 腿・脛骨顆面に代わる荷重支持の機能を有する. 脛骨 インサート面の後方部分は, 図の白矢印で示すように, 前後方向に平面状になっており,ボールーソケット部を 中心とした回旋運動がしやすい構造になっている.

最後に, CFK(図 1(c))はいわば, NRG と Bi-surface それぞれの長所を併せ持った人工膝関節である. 図に 示すように, NRG のポスト-カム部と Bi-surface のボー ルーソケット部とを一体化した球面軸受を有する点に 最大の特徴がある. CFK の主たる特長は, 第一にソケ ット後緑とボールとの衝突 (インピンジ) を回避する ためボール位置をオフセットさせていること, 第二に 深屈曲時にも内・外旋を自由に行なえるようボールソケット (=ポスト-カム) 部を球面軸受構造としてい ること, 第三に完全深屈曲状態においてもポスト-カム 部での接触が維持できるようソケット面を前方上方部 に突き出す構造としていること, などである.

図 2 は 3 種の人工膝関節の膝屈曲角に伴う関節面接 触様式を示した模式図である.

NRG では, 膝角度 $0^{\circ} \sim 60^{\circ}$ の間は内・外側顆面接触 のみが行われ, 膝角度 $60^{\circ}$ 近傍からポスト-カム間の接 触が始まる. その後, 内・外側顆面とポスト-カムの 3 


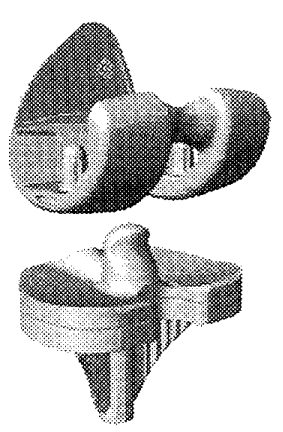

(a) NRG

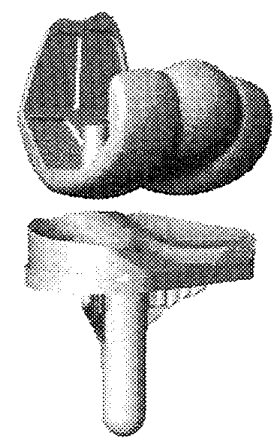

(b) Bi-surface

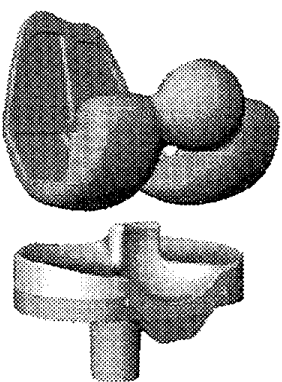

(c) CFK

Fig.1 Overviews of typical three types of posterior stabilized knee prostheses designed to attain high/deep flexion of a knee

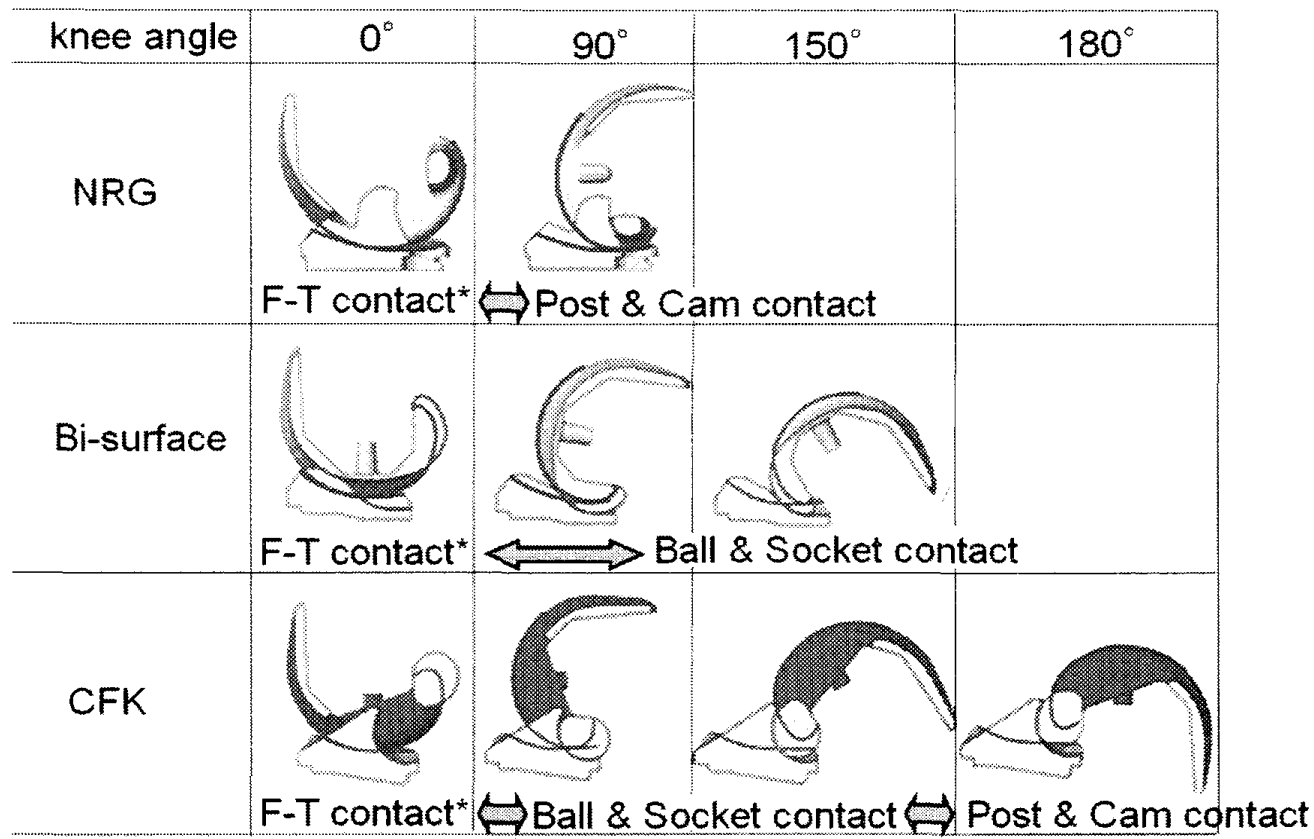

Fig.2 Articulation modalities of three prostheses according to knee angle

個所での接触が行われる. ポスト-カムは大腿骨のロー ルバックを誘発するためであって，ここでの荷重支持 性は高くない.とくに滕屈曲 $100^{\circ}$ 以上ではポスト-カ ムは荷重支持の働きを持たない.

Bi-surface では, 膝角度 $80^{\circ}$ 近傍で大腿骨ボールが脛 骨ソケットと接触し始める．Bi-surface では，膝角度 $80^{\circ}$ 近傍で大腿骨ボールが脛骨ソケットと接触し始め る.したがって, 膝角度が $80^{\circ}$ 以上では, 内・外側顆 面とボールーソケットの 3 個所での接触が行われる. 膝 角度 $120^{\circ}$ 近傍ではボールーソケット部のみでの接触と なる. 膝角度 $130^{\circ}$ 以上の深屈曲位においてもボールソケットが接触するように設計されているが，実際に は, ボールーソケット間が離机たり, ボールがソケット
後縁でインピンジしたりする場合があり, 最大㯟屈曲 角度は $150^{\circ}$ までに止まっている.

CFK は完全伸展位から完全深屈曲位に至るまで, 大 腿・脛骨間の顆面接触に始まり, ボールーソケット接触 を経て，ポストーカム接触まで連続的な接触が行われ， 逆に, 完全深屈曲位から完全伸展位に至る動作でも上 記と逆の経路をたどって連続的な接触が行われる.

\section{3. 光弾性実琚}

\section{1 光弾性法の原理 ${ }^{(12)}$}

応力下にある物体に偏光を通過させると偏光は 2 主 応力方向に分離し, 分離した 2 光波の位相差は主応力 
差に比例する．物体を単色光の下で観察すると 2 光波 の位相差, すなわち主応力差 $\left(\sigma_{1}-\sigma_{2}\right)$ を縞次数 $\mathrm{n}$ で力 ウントできる：この関係を整理すると次式,

$$
n=\left(\sigma_{1}-\sigma_{2}\right) \alpha t
$$

が成り立ち，ここで $\left(\sigma_{1}-\sigma_{2}\right)=$ 主応力差 $\left(\mathrm{Kg} / \mathrm{mm}^{2}\right), n=$ 測定点での縞次数, $\alpha=$ 光弾性感度 $(\mathrm{mm} / \mathrm{Kg}), t=$ スラ イス試片の厚さ $(\mathrm{mm})$, である.

応力凍結型光弾性法は三次元物体の応力解析に用い られる一般的な方法である. 重合体が, その軟化温度, または臨海温度（ガラス遷移温度）よりわずか高い温 度まで加熱されると, 物体自身はその弾性挙動を維持 するものの，剛性，たとえば弾性係数は著しく低下す る、物体がこの温度下で荷重を負荷されたまま，温度 を常温まで下げた場合，応力状態は物体内に”凍結” される(14). したがって, 常温時に高荷重を加えた場合 と等価な縞が高温時では，はるかに低い荷重で観察で きる。

応力凍結後, 余分な荷重をかけないようにして測定 対象物体をスライス状に切断し，各スライスでの忘力 を二次元手法で解析する.

対象物体の光弾性感度指数は, 対象物体上同一素材 の単純支持梁に単純曲げをかけた時の縞観察を基に求 めることができる.

\section{2 脛骨インサートモデル}

以下の上うにして脛骨インサートモデルを作成した. 最初に,インサートの精密鋳型をシリコンエポキシゴ ム(KE-RTV, Shinetsu Silicone Co., Japan)で作成したイ ンサートモデル用の溶剤は, $43^{\circ} \mathrm{C} て ゙, 2$ 種のアラルダ 个ト(GY 250 and GY 1252, Ciba Geigy Co., Japan)之硬化 剤(HY 950, Ciba Geigy Co.) を 1:1:0.2 の比率で混合し た. 攪找器を使用し, 液融合過程で泡が生じないよう 注意した。この溶剤をシリコーン鋳型に注入し，室温 で 12 時間放置した. 図 3 に本研究で対象としている 3 種の人工関節のインサートのモデルを示す.

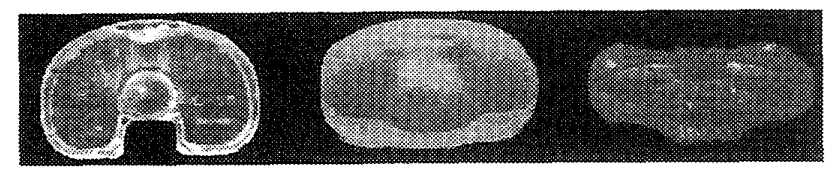

(a) NRG
同一素材で作成したキャリブレーションプレートに 種々の荷重を負荷して 4 点支持方式による単純曲げモ 一メントを加え, 応力凍結後の縞観察を行った. 以上 の操作を $10^{\circ} \mathrm{C}$ 間隔で温度設定した環境下で $20^{\circ} \mathrm{C} \sim$ $100^{\circ} \mathrm{C}$ の範用に渡って繰り返し, 応力凍結時の温度と フリンジ応力との関係を求めた. その結果, モデル素 材に最も明瞭な光弾性縞が現れる荷重条件は $2 \mathrm{~kg}$ であ ることを見出した. $2 \mathrm{~kg}$ 荷重負荷時の応力凍結温度と 光弾性感度との関係を図 4 に示す．同図を基に，モデ ル素材のガラス遷移温度は $90^{\circ} \mathrm{C}$, この時の光弾性感度 は $\alpha=37.6(\mathrm{~mm} / \mathrm{Kg})$ と求まる.

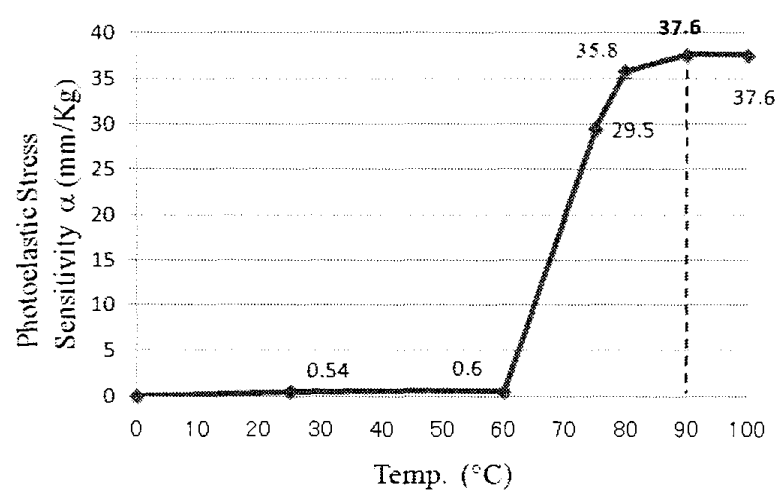

Fig.4 Fringe value vs. temperature for frozen stress

\section{3 荷重装置}

図 5 に実験装置の外観を示す大腿・脛骨両コンポ 一ネントの相対姿勢を任意に設定した状態で, 両コン ポーネント間に一定荷重をかけることができるよう荷 重負荷装置を設計した。図7で天井フレームは4隅の 支柱をガイドとして上下にスライドできるようになっ ている.この天井フレーム下面に大腿骨コンポーネン トが，大腿骨軸が垂直となるような姿勢で取り付けら れている. 天井フレ一ム上面に乗せる鍾の重量で大 腿・脛骨コンポーネント間の負荷荷重を調整する。一 方, 脛骨インサートは脛骨トレイを介して 6 自由度ユ ニバーサルジョイントに取り付けており，ユニバーサ ルジョイントは設置位置を調整した上でフレーム土台 に固定している.

次に，モデル素材の光弾性感度指数とガラス遷移温 度を求めるため, 以下の基礎実験を行った. モデルと 


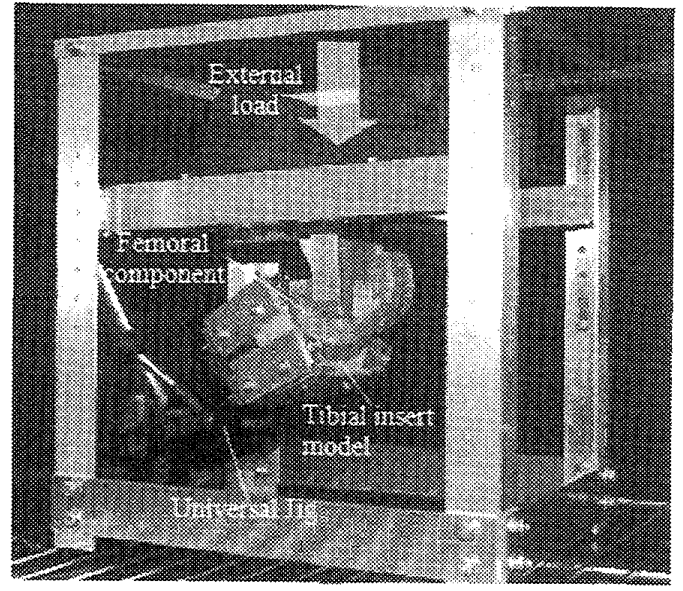

Fig.5 Experimental set-up

\section{4 実験方法}

3.3 で述べた荷重装置のユニバーサルジョイントを 調整して 0 加ら 120 ままで 30 間隔に膝屈曲角度を設定 した. NRG では 120 以上の膝屈曲設定ができなかっ たため, 屈曲角 $150^{\circ}$ 以上は設定範囲に含めなかった. 各膝屈曲角度ごとに, 以下に述べる手順で荷重を加え， 応力凍結試料を作成した. 腅屈曲角を設定後, 天井フ レーム, 大腿骨コンポーネントおよび錘の総重量が 2Kg となるよう錘の重量を調整し，これを天井フレー ム上面に乗せた後, 装置全体を制御炉内に格納した。 次いで, 文献 ${ }^{(14)} に$ 従い, 炬内温度を 1 時間あたり $1{ }^{\circ} \mathrm{C}$ の速度で上昇させ, 最高温度 $90^{\circ} \mathrm{C}$ の状態を 30 分間 保持した後, 1 時間あたり $1{ }^{\circ} \mathrm{C}$ の速度で室温まで冷却 させた. 冷却後, 装置から取り外したモデルを, 電動 ノコで, 図6に示すように $4 \mathrm{~mm}$ 間隔で切断し， 1 モ デルあたり 15 枚のスライス片を作成した. 両端の破 片は破亲した. 切断作業中はモデルを水冷し, 切断に よる摩擦熱でモデルが再加熱されるのを防いだ(15).

以上のようにして，1 種類の人工膝関節インサート に付き， 5 種類の膝角度を対象に，各 15 枚ずつ, 合 計 75 枚のスライス片を作成した. 最後に, 各スライ ス片を光弾性装置下に置き, 縞解析を行った.

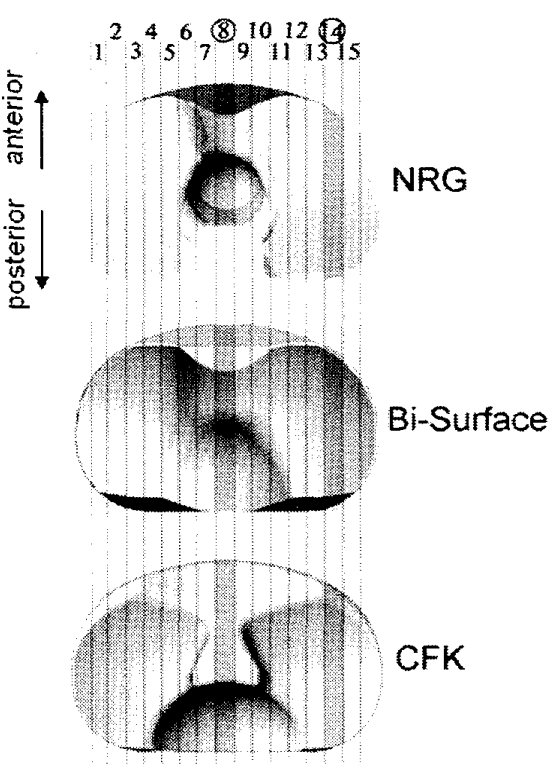

Fig.6 Two slices chosen for comparison

\section{4. 結 果}

すでに述べたように, 本研究で対象としている3 種 の高・深屈曲対応型人工膝関節では，伸展位から低・ 中屈曲位までは大腿・脛骨間の内・外側顆面接触が行 われ，高・深屈曲ではボールーソケットまたはポスト 一カム部での接触が行われる. そこで，図 6 に示した 中央側 (8 番) と外側（14 番）の2スライス片を対象 に, 結果を整理した.ここで, 外側スライスは主とし て低・中屈曲位での顆面接触部の応力を求めるためで あり，内側よりも適合性が悪いとされる外側での応力 を 3 種の人工関節で比較することにした．中央側は 高・深屈曲位でボールーソケットまたはポストーカム接 触部に生ずる応力を求めるためである.

図 7,8 は 3 種の人工関節の外側および中央側におけ る等色線縞パターンを各膝屈曲角ごとに示したもので ある. 図中に付した矢印は縞中心，すなわち応力集中 個所を指しており，矢印の無いスライス片では縞が生 じていない。

まず外側に付いては，図 7 を基に，等色線縞次数が もっとも高くなる個所と縞次数を次のように整理で きる. 3 種の人工関節とも, 等色線縞次数の最大值は 3.00 であり，この値は膝角度 $60^{\circ}$ の時に生じている.

NRG では屈曲角 $90^{\circ}$ で縞次数が 1.39 に減少し, 縞中 心が後方へ移動しており, 屈曲角 $120^{\circ} て ゙ は$ 縞が消失し ている. 
Bi-surfaceでは屈曲角90゚や120。では縞が認められな いことから，屈曲角 $60^{\circ}$ 以上では顆面接触が行われず, 接触部位がボールーソケットへと移行していることが 分かる.

CFK はNRG 上同様の縞変化パターンを示すが，屈 曲角 $90^{\circ}$ での縞次数は 1.22 と NGよりも低くなり, 屈曲角 $120^{\circ}$ で縞が消失している.

次に，中央側に付いては，図 8 を基に，等色線縞次 数がもつとも高くなる個所と縞次数を次のように整 理できる.

NRG は屈曲角 $90^{\circ}$ で縞次数が最大となり，その值は 3.1 である. 膝角度 $30^{\circ}$ と $120^{\circ}$ で, 小さめの縞が見られ る.また，㯟角度 $60^{\circ}$ と $90^{\circ}$ で縞の集中が見られる。

Bi-surface では, 膝角度 $0^{\circ}$ と $30^{\circ}$ で縞が生じて抢らず, 伸展位から屈曲初期にかけてボールーソケット間の接 触は生じていないことが分かる，屈曲角 $60^{\circ}$ 以降では 縞の集中が見られ, 屈曲角 $120^{\circ}$ では, 縞次数の值が 3.65 にも達していることが分かる。

CFK の場合，膝角度 $0^{\circ} \sim 60^{\circ}$ で縞が生じておらず, 滕角度 $90^{\circ}$ および $120^{\circ}$ における縞次数も,それぞれ 1.82 および 2 と低い值を示している.

表 1 は図 7，8 の結果をまとめたものであり，せん 断応力値も併せて示してある. 表中のせん断応力值は 前述したキャリブレーションプレートでのせん断応力 と光弾性縞次数との関係を基に算出している.

表 1 によれば，NRG では膝角度 $60^{\circ}$ と $90^{\circ}$ で大 腿・脛骨顆から, ポスト-カムへとせん断応力が移行し ているが, $120^{\circ}$ では大腿・脛骨顆とポスト-カムのい ずれでもせん断応力が生じていない．これは大腿・脛
骨顆はもとより, ポスト-カム部も接触しなくなるため である。

一方, Bi-surface では大腿・脛骨顆から，ボール-ソ ケットへのせん断応力の移行は滕角度 $60^{\circ}$ である. そ れ以降はボールーソケット間にのみせん断応力が生じ ており，しかもその值はかなり高い。

CFK の場合, 大腿・脛骨顆から, ボールーソケット へせん断応力が移行するのは膝角度 $90^{\circ}$ に達してか らであり,それ以降にボールーソケットあるいはポスト 一力ム間に生ずるせん断态力值もそれほど高くはない.

図 9(a)，(b)は表 1 の結果を基に，3種の人工関節の 最大せん断応力値を種々の膝屈曲角に対しプロットレ たものであり，図の(a)は外側，(b)は中央側での結果を 示す.

図 9(a)によれば，NRG とCFK の大腿・脛骨顆面に 生ずるせん断応力は，膝関節の全可動域を通じ，ほぼ 等しい変化傾向を示している. しかしながら,より詳 細に観察すると, NRG の変化パターンは CFK より一 様であり，大腿・脛骨顆面に関しては NRG の適合性 が優れていることが分かる. Bi-surface では屈曲角 $90^{\circ}$ で，もはや顆面接触が行われなくなることは既に述べ た通りである。

図 9(b)に示すボールーソケット（ポスト-カム）間の せん断応力は(a)に示した大腿・脛骨顆面間のせん断応 力に比べ, 高い值を示している. 3 種の人工関節のせ ん断応力は, 嚗角度 $90^{\circ}$ と $120^{\circ}$ の間にそれぞれ異なつ た変化パターンを示しており, Bi-surface が上昇傾向を 示すのに対し，NRG は急激に減少し，CFK はほぼ一 定値を保っている.

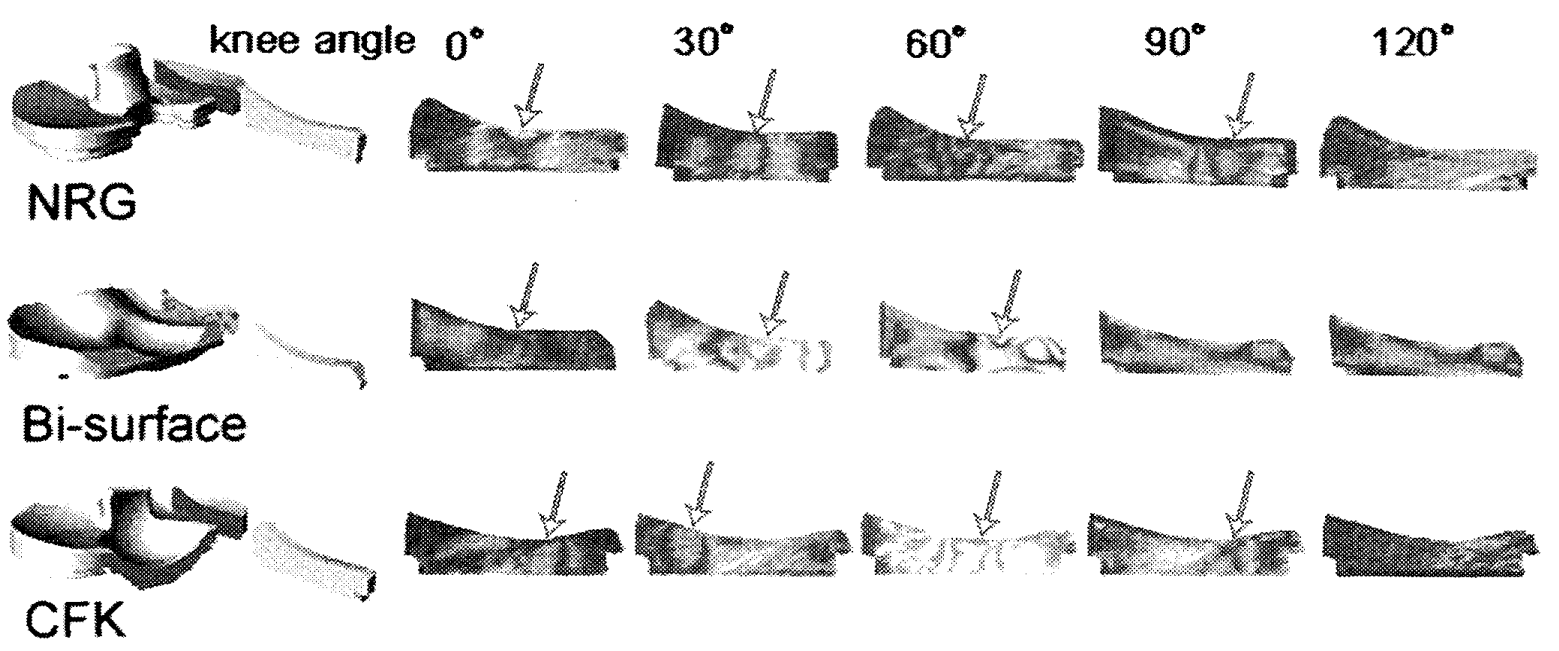

Fig. 7 Isochromatics of the slices in the lateral side.

(An arrow points the stress concentrating portion. Same as Fig.8) 

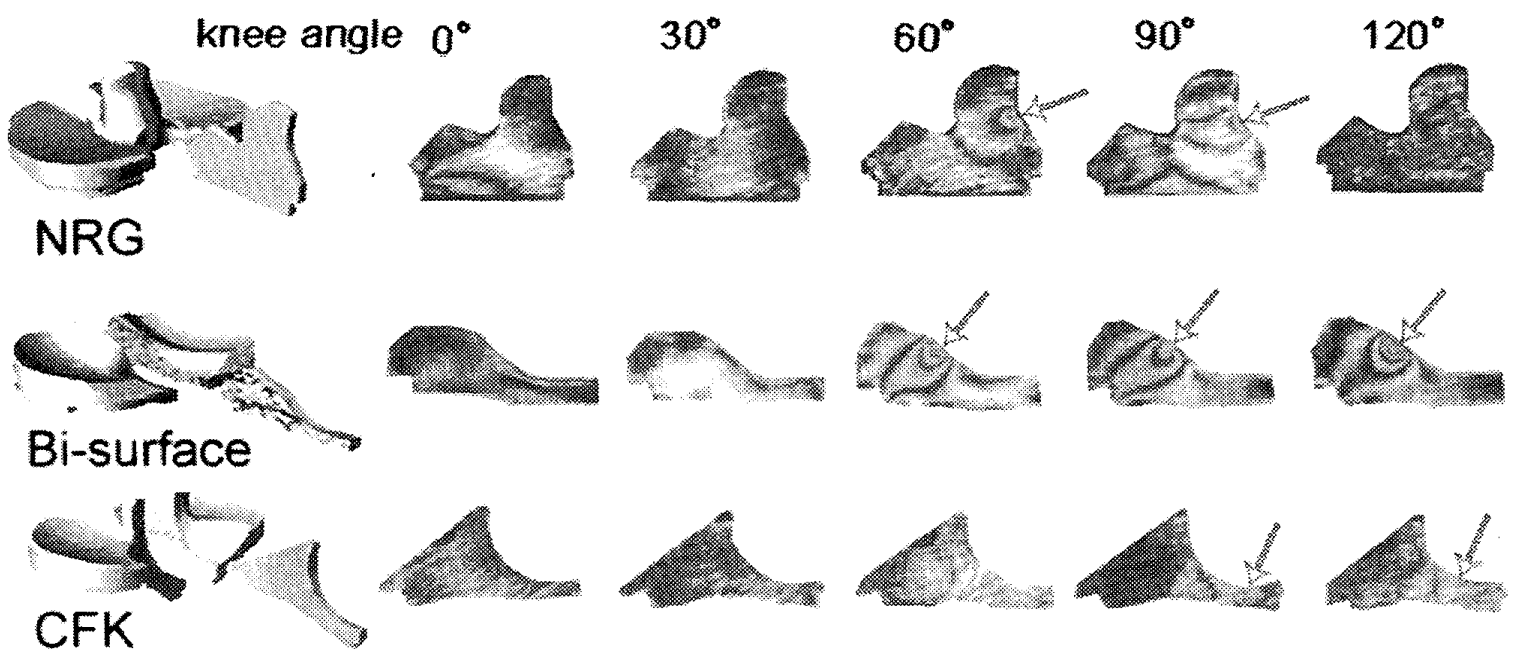

Fig. 8 Isochromatics of the slices in the mid-posterior side.

Table 1 Shear stresses in the lateral and the midposterior sides of three prostheses

\begin{tabular}{|l|r|rc|cc|}
\hline \multirow{3}{*}{ Prosthesis } & \multirow{2}{*}{$\begin{array}{l}\text { Knee } \\
\text { flexion } \\
\text { angle }\left({ }^{\circ}\right)\end{array}$} & \multicolumn{2}{|c|}{ Lateral side } & \multicolumn{2}{c|}{ Midposterior side (post-cam) } \\
\cline { 3 - 6 } & 0 & Fringe order & Shear stress (kPa) & Fringe order & Shear stress (kPa) \\
\hline NRG & 1.39 & 52.5 & 0.00 & 0.0 \\
& 30 & 1.82 & 60.8 & 0.00 & 0.0 \\
& 60 & 3.00 & 71.1 & 2.50 & 70.8 \\
& 90 & 1.39 & 51.8 & 3.10 & 0.8 \\
\hline Bi-surface & 120 & 0.00 & 0.0 & 0.00 & 0.0 \\
& 0 & 1.39 & 54.1 & 0.00 & 0.0 \\
& 30 & 1.82 & 74.1 & 0.00 & 109.2 \\
& 60 & 3.00 & 78.2 & 3.10 & 109.2 \\
& 90 & 0.00 & 0.0 & 3.10 & 128.6 \\
\hline CFK & 120 & 0.00 & 0.0 & 3.65 & 0.0 \\
& 0 & 1.39 & 54.1 & 0.00 & 0.0 \\
& 30 & 1.22 & 49.7 & 0.00 & 53.9 \\
& 60 & 3.00 & 78.2 & 0.00 & 54.9 \\
\hline
\end{tabular}

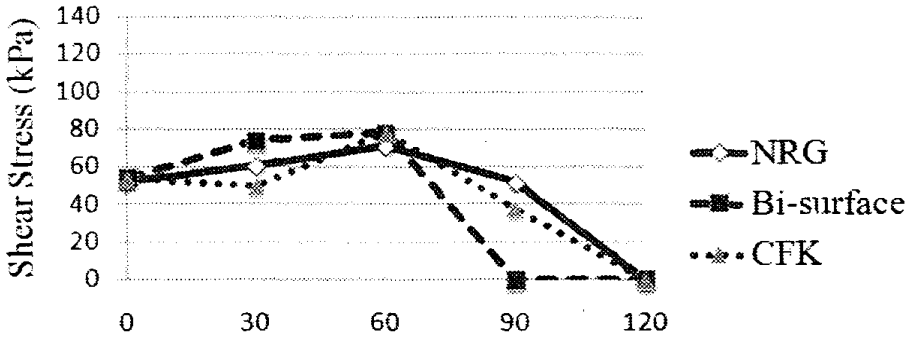

Knee flexion angle $\left(^{\circ}\right)$

(a) lateral side

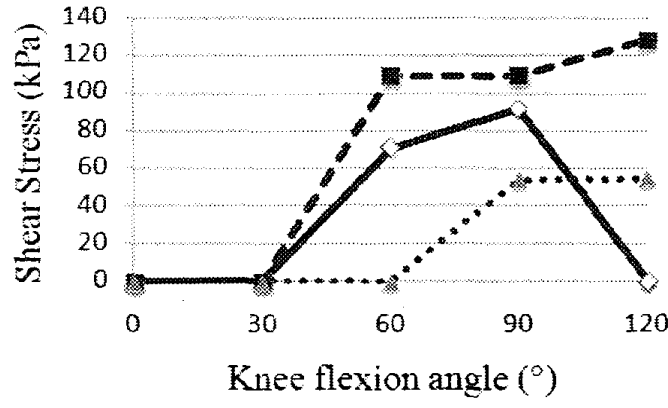

(b) mid-posterior side

Fig. 9 Comparison of the maximum shear stresses for the three prostheses as a function of knee angle. 


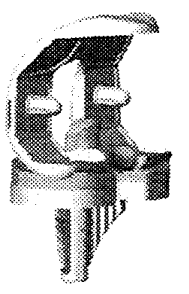

(a) NRG

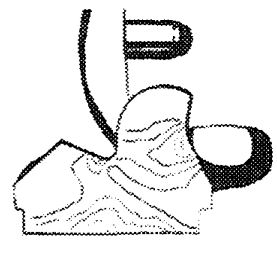

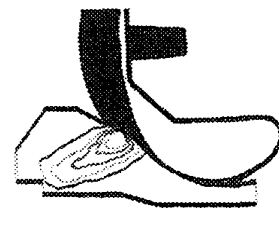

(b) Bi-Surface
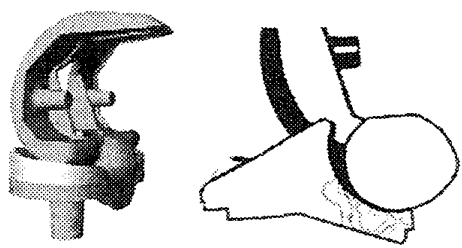

(c) CFK

Fig.10 Stress distribution patterns on the post-and-cam or the ball-and-socket at $90^{\circ}$ of knee flexion

NRG の応力値の急落は $120^{\circ}$ でポスト-カムが接 触しなくなるためである．Bi-surface は膝屈曲角 $120^{\circ}$ で 3 種の人工関節の全屈曲角度中, もっとも 高い応力值を示し，この角度でボールがソケット前 縁でインピンジしている可能性が高い。これらに対 し, CFK の応力值は低く, しかも一定した値を示し ている.

図 10 は膝屈曲角 $90^{\circ}$ の場合を例に，3種の人工関 節インサートの中央側スライスに生じる縞パターン を人工関節姿位とともに示したものである，図に上 れば，ポストーカムまたはボールーソケット部での縞 の集中個所と分布状態は，3 種の人工関節で多様に 異なっている.

$\mathrm{NRG}$ の場合, ポストとカムの接触個所以外に，イ ンサート底面に至るまでの広範囲の縞分布が認めら れる，インサート底面に現れる縞分布はポスト基肢 部に作用する曲げモーメントの影響によるものと思 われる.

Bi-surface での縞集中個所はソケット前縁部に偏 っており，インピンジとともに，ボールがソケット 溝を乗り越えて前方へ脱臼することも危惧される.

CFK の場合，屈曲角 $90^{\circ}$ では縞集中個所は未だソ ケット部に止まっており，これがポスト部へ移行す るのは膝屈曲角 120 以以降であると予想される. CFK で懸念される点は，屈曲角 $90^{\circ}$ で荷重を分担してい る個所のソケット厚みが薄いことである.

\section{5. 考察}

筆者らの研究グループでは屈曲角 $180^{\circ}$ の完全深 屈曲位の実現を目指した人工膝関節 CFK を開発し, 可動性, 安定性, 耐久性に関する評価を実施中であ るが，患者への適用を経ずにいかにして耐久性評価 を行うかが大きな課題であった。

人工膝関節の耐久性は主としてポリエチレンイン サ一トの耐摩耗性に依存している。ささらに，インサ
一トの耐摩耗性は大腿骨コンポーネントとの滑動形 態や接触部応力に依存している.ただし，人工関節 装着者が正座や蹲路などの深屈曲動作を行う頻度は 低く，動作速度も遅いため，滑動形態よりも関節面 の接触部表面やその下層に生じるせん断応力の方が より重要な評価パラメータとなる.

以上により, 本研究では, 光弾性法を用いて, CFK インサートのせん断応力とその分布を求めることに した。しかしながら，下肢運動時に膝関節にかかる 正確な荷重值は不明であり，平地歩行を対象とした シミュレーション結果はいくつか報告されているも のの ${ }^{(16)}$, 高・深屈曲位における荷重值については

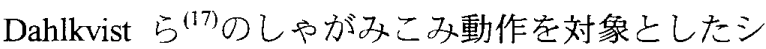
ミュレーション結果以外に報告例を見出せなかった. そこで, 本研究では, CFK 同様に高・深屈曲動作の 実現を目指した他種人工膝関節を対象として，同一 条件下で 3 種の人工関節に生じる応力值を比較する ことで, CFK の耐久性に関する間接的評価を試みた.

実験結果によれば，膝角度 $90^{\circ}$ 以下では，NRGの 大腿・脛骨関節顆面の接触点力凌屈曲に伴って後方 移動（ロールバック）しており（図 7），この間の 応力值は相対的に低く，安定した值を示した（図 9(a)）。このことはNRG の大腿・脛骨関節顆面が最 適形状に設計されており，たとえば歩行動作のよう な低・中屈曲動作時の安定性や耐久性に優れている ことを意味する。

一方, 膝角度 $60^{\circ} \sim 90^{\circ}$ でポスト-カム間に生ずる応 力値はやや高く（図 9(b)），ポスト-カムの形状は荷 重支持性の点では最適でないと判断される. また, 膝角度 $120^{\circ}$ 以上ではポスト-力ム間で応力を生じて いないが，これは NRG が 120 以上の膝屈曲を達成 できないため，光弾性縞の測定が不可能であったた めである.

筆者らの予想に反して，Bi-surface のボール-ソケ ット間ではかなり高い応力值が生じており(図 9(b)), 光弾性縞分布を詳細に観察した結果, ソケット前縁 
で応力集中（インピンジ）が生じていることが分か った. Bi-surface で正座が可能であるとの報告(6)もあ るが，上記インピンジやボールがソケット溝を乗り 越えて前方へ脱臼する危険性があるため, 深屈曲位 における安定性や耐久性を完全に保証しているとは 言い難い.

CFK の場合, 図 9 (a) に関する説明文中でもすで に述べたように，膝角度 $90^{\circ}$ 以下では，大腿・脛骨 関節顆面の応力值は低いものの安定しておらず，大 腿・脛骨関節顆面の適合性は NRG ほどには高くな い. 一方, 膝角度 $90^{\circ}$ 以降で, ポスト-力ム間の応力 值は低くて安定した值を示し, 球面軸受構造の特長 が活かされていることを確認できた. 人工関節で 高・深屈曲位での安定性と耐久性を同時に満足させ ることはできないとの指摘もあるが(2)，CFK ならば 深屈曲位での安定性亡耐久性を満足できると考えら れる.ただし，CFKでは低・中屈曲位での大腿・脛 骨関節面の適合性が NRG に比べ劣っており，大腿・ 脛骨関節面の形状についての検討が必要となる.

紙面の都合上，本論文では，1枚の外側スライス (図 6, スライス 14 番) での結果を例に，大腿・脛 骨関節顆面接触部の応力を評価したが，実際には， 15 枚すべてのスライス片での結果を踏まえ，上記 14 番での結果が大腿・脛骨関節顆面接触部の応力を 代表していることを確認している，同様に，スライ ス 8 番での結果は, あくまでボール-ソケットやポス ト-カム接触部の応力を代表したものであることを 確認している.

本研究の限界は, 膝屈曲角度をパラメータとして, 一定方向に一定荷重を掛けた状態での静的応力の測 定に留まっていることであり, 患者に装着した人工 滕関節で実際に生じている応力を反映したものでは ない. しかしながら，たとえば，しゃがみ込み動作 中の筋力值および筋力による関節力の増減に関する in vivo データは不明であり, 不確かな関節力データ を実験条件として 3 種の人工関節の応力を比較する より，一定荷重条件下で比較する方が結果の解釈が 容易である. 現用されている他種人工膝関節を対照 例として, 同一条件下での応力值を比較することで, 患者への装着が認可されない CFK の耐久性を相対 的に評価することは可能である. その結果, 高・深 屈曲位に CFK のポスト-カム部に生じる応力は, 他 の 2 人工膝関節に生じる応力に比べ, 十分低く, 安 定していることが分かった.
人工関節の耐久性や耐摩耗性の評価には，シミュ レー夕試験を実施するのが通例であるが，歩行動作 と異なり，正座やしゃがみ込み動作のキネマテック スを定式化することは極めて難しく，また，これら の動作を行う頻度も低い. よって光弾性応力解析は シミュレー夕試験を代行し得ると考えられる.

本研究の今後の課題は, 序論でも述べたように, 同一条件化に打ける FEM 解析結果との相互比較・ 検証である. ただし, FEM解析の場合, 対象人工関 節の CAD データを入手できないと FEM モデルを作 成し難いという問題がある. 本研究では, CADデー 夕を入手した人工関節を対象に FEM 解析を行い, 光弾性実験結果と良く一致した結果を得ている.

上記の過程で得られた知見は, FEM 解析と異なり, 光弾性実験の場合, 実験の都度, 結果が幾分異なる という点である。この違いは, 必ずしも実験手順の 不確実さや測定誤差だけでなく, 応力の不安定性 ${ }^{(18)}$ に起因すると考えられる，そうであるならば，実際 の TKA 膝の摩耗・耐久性はある程度の幅をもって 評価されなければならない。光弾性実験はこの評価 幅推定にも役立つと考えられ，詳細は今後の検討課 題である.

上記以外の今後の予定としては, これまでの荷重 負荷装置に変えて，荷重センサ一を取り付けたロボ ットアームを使用し, 応力凍結法に代えて散乱光光 弾性法を適用することにより, 種々の膝運動での動 的応力縞をリアルタイムで測定することを計画して いる.

\section{6. 結 論}

本研究では, 高・深屈曲動作の実現を目指した人 工膝関節を対象に，ポリエチレンインサートのせん 断店力値亡その分布を光弾性法で測定した. 対象亡 した人工膝関節は，現用 PS 型で高屈曲が可能なよ うに改良された NRG, 現用されている深屈曲対応型 Bi-surface 抢よび完全梁屈曲実現を目指し新規開発 中の CFKの 3 種である.

膝屈曲角 $90^{\circ}$ 以下では, 大腿・脛骨間の顆面接触 が行われるため, 主として, 外側顆スライスの縞観 察を行った. その結果, NRG がその高い適合性のゆ えにもっとも低い応力値を示し, 次いで CFK, Bi-surface の順に低い応力値を示した.

睖屈曲角 $90^{\circ}$ 以降では, ボールーソケットやポストカムで接触が行われるため, 主として, 中央側のス 
ライスでの縞観察を行った. その結果, CFKがその 高い適合性のゆえにもっとも低い応力值を示し，次 いで Bi-surface, NRG の順に低い応力值を示した. 膝 角度 $120^{\circ}$ 以降では，NRG はポストーカム間の接触が 行われず，脱臼の可能性があることが分かった。

謝辞

本研究は学術振興会科学研究費補助金，基盤 $\mathrm{B}$ (2008, 20300161)によって行った. 本研究にご協力頂 きました佐賀大学医学部整形外科佛淵孝夫教授，久 留米工業大学工学部山本耕之准教授にお礼申し上げ ます。

\section{文献}

(1) Kadoya, Y., Implant Design of TKA for Deep Knee Flexion (in Japanese), SEIKEI - SAIGAIGEKA, Vol.47, Kinbara Publication, (2004), pp.129-135.

(2)http://www.adherents.com/Religions_By_Adherents.h tml

(3) Akagi, M., Deep Knee Flexion in the Asian Population, Total Knee Arthroplasty, Vol.VI, (2005), pp.311-316.

(4) Nakayama, K., Matsuda, N., et al., Contact Stress At the Post-cam Mechanism in Posterior-Stabilised Total Knee Arthroplasty, The Journal of Bone \& Joint Surgey, Vol.87-B, No.4, (2005), pp.483-488.

(5) Morra, E.A. and Greenwald, A.S., Polymer Insert Stress in Total Knee Designs During High-flexion Activities: A Finite Element Study, The Journal of Bone \& Joint Surgey, Vol.87-B, (2005), pp.120-124.

(6) Huang, H., Su, J.Y., and Wang, G., The Early Results of High-flex Total Knee Arthroplasty: A minimum of 2 Years of Follow-up, The Journal of Arthroplasty, Vol.20, No.5, (2005), pp.120-124.

(7) Akagi, M., Nakamura, T., et al., , The Bisurface Total Knee Replacement: A Unique Design for Flexion, The Journal of Bone and Joint Surgery, Vol.82-A, No.11, (2000), pp.1626-1633.

(8) Hirokawa, S., Todo, M., et al., Development and Evaluation of Prosthesis Capable of Making a Complete Knee Flexion (in Japanese), Transactions of the Society of Clinical Biomechanics, Vol.28, (2007), pp.225-231.

(9) Shashishekar, C. and Ramesh, C.S., Finite Element Analysis of Prosthetic Knee Joint Using ANSYS, Biomedicine and Health, Vol.12, pp.65-72 (2007).

(10) Todo, M., Nagamine, R., et al., Stress Analysis of PS Type Knee Prostheses under Deep Flexion, Journal of Biomechanical Science and Engineering, Vol.2, No.4, (2007), pp.237-245.

(11) Ramesh, K. and Pathak, P.M., Role of Photoelasticity in Evolving Discretization Schemes for FE Analysis, Journal of Experimental Techniques, Vol.23(4), (1999), pp.36-38.
(12) Tamaki, M., Tomita, T., et al., In Vivo Kinematic Analysis of a High-Flexion Posterior Stabilized Fixed-Bearing Knee Prosthesis in Deep Knee-Bending Motion, The Journal of Arthroplasty, Vol.23, No.6, (2008), pp.879-885.

(13) Stewart, B.L. and Edwards, R.O., Removable Partial Denture Design: A Photoelastic Study, Journal of Biomedical Material Research, Vol.18, (1984), pp.979-990.

(14) Theocaris, P.S. and Gdoutos, E.E. Matrix Theory of Photoelasticity, Springer Series in Optical Sciences, Vol.11, (1979), pp.132-137.

(15) Wang, M., Zang, M., et al., Photoelastic Study of the Effects of Occlusal Morphology on Tooth Apical Stress from Vertical Bite Forces, Journal of Contemporary Dental Practiceournal of Experimental Techniques, Vol.5(1), (2004), pp.74-93.

(16) Komistek, R.D., Kane, T.R., et al., Knee Mechanics: a review of past and present techniques to determine in vivo loads, Journal of Biomechanics, Vol.38, (2006), pp.215-228.

(17) Dahlkvist, N.J., Mayo, P., et al., Forces during Squatting and Rising from a Deep Squat, Engineering in Medicine, Vol.11(2), (1982), pp.69-76.

(18) Sakai, R. and Mabuchi K., Revision of the Available Concepts concerning the Fixation of Hip Joint Prostheses based on Mathematical Analysis (in Japanese), Transactions of the Society of Clinical Biomechanics, Vol.22, (2001), pp.415-419. 